\title{
Presence of roosters in an alternative egg production system aiming at animal welfare
}

\author{
Dayana Cristina de Oliveira Pereira ${ }^{1 *}$, Késia Oliveira da Silva Miranda ${ }^{2}$, Luiz Carlos Demattê \\ Filho', Gustavo do Valle Pereira', Sonia Maria De Stefano Piedade ${ }^{3}$, Patricia Rodrigues Berno ${ }^{4}$ \\ ${ }^{1}$ Centro de Pesquisa Mokiti Okada, Ipeúna, SP, Brazil. \\ 2 Universidade de São Paulo, Escola Superior de Agricultura "Luiz de Queiroz", Departamento de Engenharia de Biossistemas, Piracicaba, SP, \\ Brazil. \\ ${ }^{3}$ Universidade de São Paulo, Escola Superior de Agricultura "Luiz de Queiroz", Departamento de Ciências Exatas, Piracicaba, SP, Brazil. \\ ${ }^{4}$ Universidade Federal de Mato Grosso do Sul, Campo Grande, MS, Brazil.
}

ABSTRACT - The objective of this study was to evaluate the effect of the presence of roosters on welfare and egg production of laying hens reared in an alternative system. Two breeding systems were established: barn 1 - laying hens reared without roosters (4500 birds); and barn 2 - laying hens reared with roosters (4500 layers and 250 roosters). In the poultry facilities, microclimate, egg production, mortality rate, and bird behavior were evaluated. Microclimate analysis showed that the birds were subjected to periods of constant heat stress, except for the morning hours. However, even under these conditions, egg production results and mortality rate were consistent with the indices recommended in the Isa Brown management guide in the barn with roosters; the indices obtained were even better and were characterized by higher egg production and lower mortality rates. In addition to productivity benefits, the presence of roosters broadened the behavioral repertoire of the birds due to the introduction of reproductive behaviors. Moreover, there was a significant decrease in the tolerance-reflex behavior, which is associated with the impossibility of displaying reproductive behaviors. This alternative egg production system proved to promote animal welfare since it provides and stimulates the display of behaviors considered important for birds.

Key Words: behavior, enthalpy, husbandry environment, laying hens

\section{Introduction}

Along with issues concerning environmental preservation and food safety, animal welfare is an issue of great impact in the media and productive environments. This scenario has been further impacted by the population awareness of the productive process, as well as by the demand for food with differentiated quality attributes (Pereira et al., 2015b).

With regard to poultry farming, there has been extensive criticism on the practices involved in commercial egg production. Images of beak-trimmed birds and birds reared in the extremely confined spaces of battery

Received: April 18, 2016

Accepted: November 24, 2016

*Corresponding author: dayana.pereira@cpmo.org.br

http://dx.doi.org/10.1590/S1806-92902017000300001

How to cite: Pereira, D. C. O.; Miranda, K. O. S.; Demattê Filho, L. C.; Pereira, G. V.; Piedade, S. M. S. and Berno, P. R. 2017. Presence of roosters in an alternative egg production system aiming at animal welfare. Revista Brasileira de Zootecnia 46(3):175-184.

Copyright (C) 2017 Sociedade Brasileira de Zootecnia. This is an Open Access article distributed under the terms of the Creative Commons Attribution License (http://creativecommons.org/licenses/by/4.0/), which permits unrestricted use, distribution, and reproduction in any medium, provided the original work is properly cited. cages are truly moving. A major challenge in the layer industry is housing due to the shift from conventional cage housing to alternatives like enriched colonies or cage-free (Thaxton et al., 2016).

In an attempt to make animal welfare a less subjective topic by promoting good welfare and allowing inspection in a productive system, the Farm Animal Welfare Council (FAWC, 1993) has developed the following concept of five freedoms, outlining five aspects of animal welfare under human control. The concept includes: nutritional freedom from hunger and thirst; environmental - freedom from discomfort; physical - freedom from pain, injury, and disease; behavioral - freedom to express normal behavior; and psychological - freedom from fear and distress. The forth one determines that animals must be reared under conditions in which they can exhibit their natural behaviors, such as scratching, wing-flapping, and perching, among others. Accordingly, the presence of roosters in the production system is an important factor, since reproductive behaviors are natural to this species, although, except in rare cases, egg production systems do not utilize roosters.

Furthermore, the behavior of the birds is strongly influenced by the environment to which they are subjected, because the homeostasis mechanism is only effective when 
the temperature is within the range required by the animals (Pereira et al. 2015a).

In view of the lack of research on this topic, the present study aimed to evaluate the effect of the presence of roosters on the welfare and productivity of laying hens reared in an alternative egg production system.

\section{Material and Methods}

This study was carried out according to the ethical principles and was approved by the local Research Ethics Committee. Two adjacent commercial barns located in Ipeúna, SP, Brazil $\left(124^{\circ} \mathrm{SE}\right.$ and $\left.310^{\circ} \mathrm{NW}\right)$ were used in the experiment. Dimensions of barns 1 and 2 were $9.8 \times 69.0$ $\times 3.0$ and $9.8 \times 70.9 \times 3.0 \mathrm{~m}$, respectively, both equipped with automatic feeders and drinkers, wooden perches, nests for egg laying, fans, and foggers. There was one nest box for every six laying birds, totaling 750 nest boxes of $0.30 \times 0.32 \times 0.45 \mathrm{~m}$ in size in each barn. The floor area was covered with wood shavings of $0.10 \mathrm{~m}$ height in both barns.

The number of feeders and drinkers and the perch space were defined according to the number of birds, in compliance with the Animal Care standards established by the Humane Farm Animal Care (HFAC, 2014).

Following the guidelines developed by the company, artificial light sources were used after the birds reached $50 \%$ lay. Accordingly, an intermittent lighting program $(15 \mathrm{~h}$ of continuous light followed by $9 \mathrm{~h}$ of darkness) was used in both barns with fluorescent lights at an intensity of 40 lux.
Isa Brown laying hens and roosters aged 15-31 weeks were investigated to assess the period between the onset and peak of egg production. All birds were initially reared together in the same space. The alternative egg production system was characterized by rearing the birds on the floor, in compliance with the standards established by the HFAC (2014). During the experimental period, the birds in the two barns were provided ad libitum food without the addition of antibiotics, chemotherapeutic agents, and products of animal origin. The diets were formulated according to the Isa Brown management guide (Hendrix Genetics, 2012-2013).

The effect of the presence of roosters was thus evaluated: 4500 laying hens were housed in barn 1, with housing density of 6.6 birds $/ \mathrm{m}^{2} ; 4500$ laying hens and 250 roosters were housed in barn 2, with density of $6.8 \mathrm{birds} / \mathrm{m}^{2}$. The ratio of eighteen laying hens for each rooster was defined and kept. The number of roosters was determined according to the area available in the barn. The laying hens were not removed from the barn for the introduction of the roosters to ensure greater applicability of this research.

Temperature and relative humidity data were collected inside the barns using data loggers installed at $1.50 \mathrm{~m}$ above the floor. Readings were obtained at one-hour intervals. The black globe temperature was measured using a globethermometer, which was installed in each barn. Data were recorded once weekly at $09.00,13.00$, and $17.00 \mathrm{~h}$. Black globe humidity index (BGHI) and enthalpy were calculated according to Buffington et al. (1981) and Villa Nova (1999) apud Furlan (2001), respectively.

Table 1 - Behavioral patterns evaluated

\begin{tabular}{|c|c|c|}
\hline Behavioral group & Behavior & Behavior description \\
\hline Physiological & $\begin{array}{l}\text { Drinking } \\
\text { Feeding } \\
\text { Visit to the nest } \\
\text { Time spent in the nest }\end{array}$ & $\begin{array}{l}\text { Ingestion of water from the drinker. } \\
\text { Ingestion of feed from the feeder. } \\
\text { Hen makes quick trips to the nest. } \\
\text { Amount of time the bird spends in the nest to lay eggs. }\end{array}$ \\
\hline Reproductive & $\begin{array}{l}\text { Courtship ritual } \\
\text { Mating } \\
\text { Tolerance reflex }\end{array}$ & $\begin{array}{l}\text { Roosters do a half-circle dance around the hen. } \\
\text { Mounting. } \\
\text { Hen lowers itself towards the ground in the presence of humans, similar to the } \\
\text { behavior exhibited prior to mating. }\end{array}$ \\
\hline Undesirable and agonistic & $\begin{array}{l}\text { Agitation } \\
\text { Fighting } \\
\text { Cannibalism }\end{array}$ & $\begin{array}{l}\text { Birds move quickly in an agitated way. } \\
\text { Two or more birds confront each other by bristling up the feathers of the neck } \\
\text { and by pecking and scratching each other. } \\
\text { Birds peck one another at wounds. }\end{array}$ \\
\hline Indicative of welfare & $\begin{array}{l}\text { Dust bathing } \\
\text { Flapping wings } \\
\text { Stretching legs and wings } \\
\text { Social interaction } \\
\text { Shaking and fluttering feathers } \\
\text { Preening feathers }\end{array}$ & $\begin{array}{l}\text { Birds throw dust over their bodies. } \\
\text { Stretching and moving wings up and down. } \\
\text { Stretching legs out and wings down. } \\
\text { Non-agonistic interactions among the birds, expressed by coordinated movements. } \\
\text { Birds shake their body and feathers. } \\
\text { Birds clean and straighten their own feathers using their beak. }\end{array}$ \\
\hline
\end{tabular}


Egg production and mortality rates were evaluated daily. With regard to the study of poultry behavior, the obtained data were grouped as follows: physiological behaviors, reproductive behaviors, undesirable and agonistic behaviors, and behaviors indicative of welfare (Table 1). These evaluations were performed once weekly using the scanning technique in three periods of the day: morning (08.00-09.00 h), midday (12.00-13.00 h), and afternoon (16.00-17.00 h). In addition, a joint analysis of these periods was carried out $(08.00-09.00 ; 12.00-13.00$; and 16.00-17.00 h), referred in this manuscript as the "full period". Images of the bird behaviors were captured simultaneously using cameras installed in the center of the barns opposite to each other. Observations lasted $1 \mathrm{~min}$ and were made at regular 10-min intervals, totaling twelve observations per hour, considering that each barn had two cameras.

Tolerance-reflex behavior (Figure 1) was evaluated by counting the number of birds exhibiting such behavior within thirty linear meters of the entrance door of the barn. This evaluation was performed after the end of the imagerecording period to allow analysis of the other behaviors.

A split-plot design in a randomized block was used. Data on egg production, mortality rate, meteorological variables, and behavioral variables were subjected to analysis of variance using the SAS statistical software package (Statistical Analysis System, version 9.2). Means were compared by Tukey's test at the 0.05 level of significance.

Behavioral variables were subjected to the transformation.
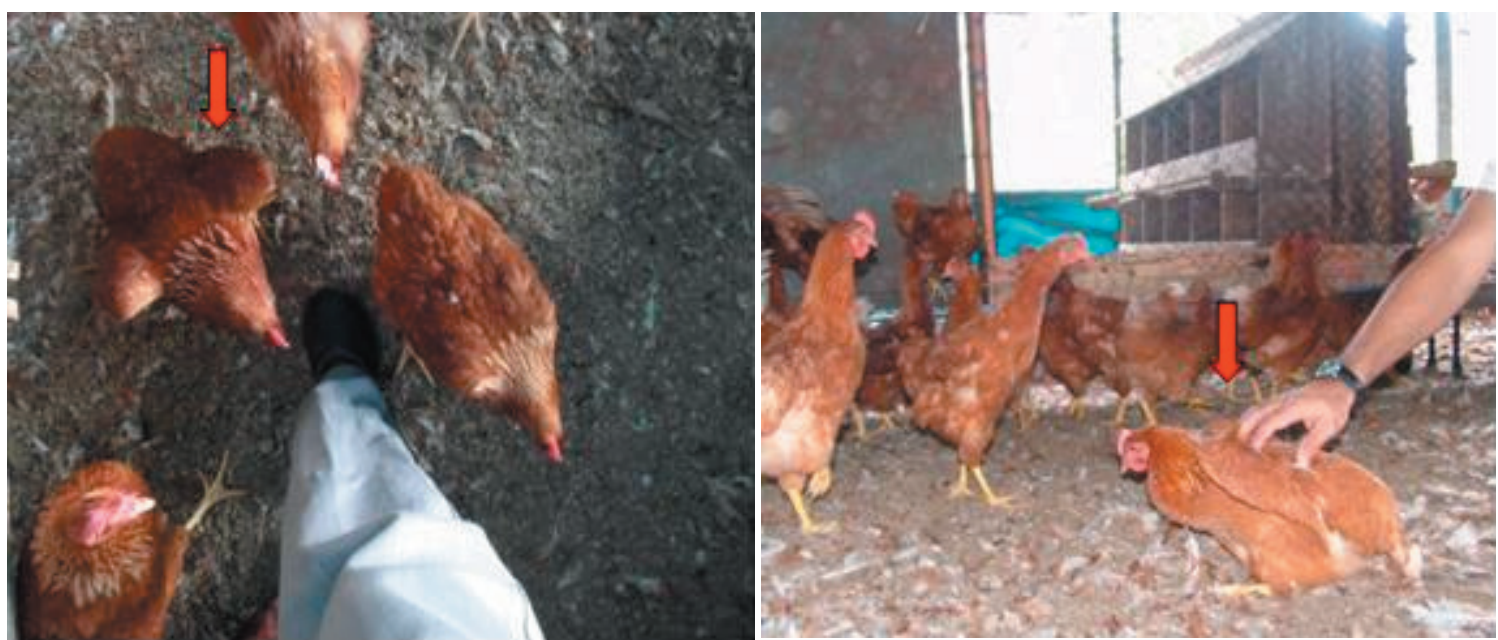

Source: private archive.

Figure 1 - Manifestation of the behavior named tolerance reflex.

\section{Results and Discussion}

Statistical analysis of temperature, humidity, BGHI, and enthalpy data using Tukey's test did not indicate evidence to reject the hypothesis of similarity between the thermal environments inside the barns (Table 2); therefore, the differences found can be attributed to the studied parameters.

The lowest temperature and the highest relative humidity index were recorded in the morning and compared with the other periods of the day (Table 2). The mean and maximum daily temperatures remained above the thermal neutral zone, most part of the day, which, according to the Isa Brown management guide (2012-2013), is in the narrow range of $21-24{ }^{\circ} \mathrm{C}$, characterizing a heat stress situation. The highest temperatures recorded throughout the experimental period were $35.6{ }^{\circ} \mathrm{C}$ and $35.7^{\circ} \mathrm{C}$ in barns 1 and 2, respectively. As expected, the relative air humidity values were significantly higher in the morning (Table 2).

According to Ferreira (2005), adult birds produce more when reared in environments with relative humidity in the range of $40-70 \%$. In the present study, except for the morning hours, a misting system was necessary so that relative humidity would not reach critical levels; i.e., values below $40 \%$.

The BGHI was significantly lower in the morning. Considering the values established by Tinôco (1998), in which a BGHI value of up to 75 is considered as thermal comfort value for laying hens, it was verified that the values obtained in the periods of midday and afternoon, between 77 and 78, were above the recommended values. Baêta and 


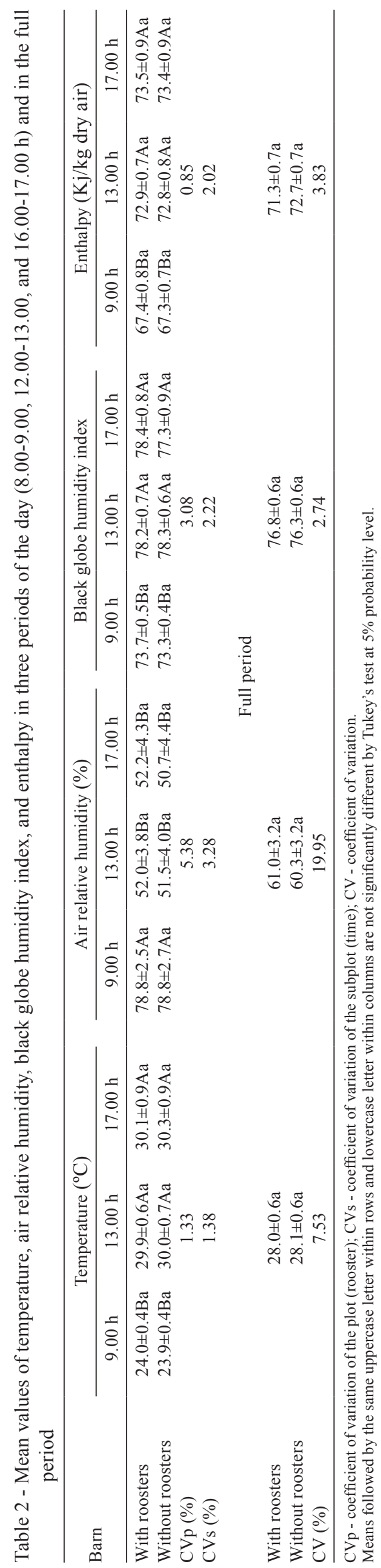

Souza (1997) reported an alert situation with BGHI value above 74. Armstrong (1994) considered BGHI of 78 as critical limit.

The analysis of the thermal conditions from the perspective of enthalpy confirms heat stress condition, characterized by values above 70 . According to Barbosa Filho et al. (2007) and Silva et al. (2006), the upper and lower enthalpy limits of the comfort zone are 70 and 64 , respectively.

The egg production of the hens reared with roosters was significantly higher $(\mathrm{P}<0.05)$ than that of the hens reared without rooster and higher than the value recommended in the Isa Brown management guide (20122013) (Table 3). The hens housed with roosters also had lower mortality rate.

The laying hens of both barns started laying eggs at 15 weeks of age. At the 18 th week of age, according to the Isa Brown management guide, the birds were supposed to reach an egg production rate of $2 \%$ (Hendrix Genetics, 2012-2013). At this age, layers housed without roosters reached egg production rates of $10.94 \%$ and those housed with roosters reached production rates of $18.87 \%$. It can be inferred that the presence of roosters was the factor determining these results, corroborating Leonard et al. (1993), who reported an improvement in the productivity of birds due to exposure to the opposite sex.

According to Newberry (1995), the presence of rooster plays an important role in environmental enrichment, providing improvements in the biological functioning of birds in captivity and consequent improvements in their health. This result can explain the lower mortality rate recorded in the barn with roosters. In absolute terms, at the end of the experimental period in the treatment with roosters, the mortality rate recorded was $0.25 \%$, whereas in the treatment without roosters the rate was $0.51 \%$ (Table 3 ).

It should be stressed that, although mortality was higher in the barn without roosters, the rate was not higher than the $1.11 \%$, as described in the Isa Brown management guide for the end of the 31 st week of age of the birds.

Table 3 - Mean values of egg production and mortality of Isa Brown laying hens reared with and without roosters and values of the Isa Brown management guide

\begin{tabular}{lcc}
\hline Barn & Egg production $(\%)$ & $* *$ Mortality $(\%)$ \\
\hline With roosters & $84.40 \pm 6.56 \mathrm{~A}$ & $0.25 \pm 0.04 \mathrm{~B}$ \\
Without roosters & $76.21 \pm 8.12 \mathrm{~B}$ & $0.51 \pm 0.10 \mathrm{~A}$ \\
Isa Brown management guide & $75.33 \pm 9.62 \mathrm{~B}$ & $0.52 \pm 0.10 \mathrm{~A}$ \\
Coefficient of variation $(\%)$ & 9.56 & 33.30 \\
\hline
\end{tabular}

** Highly significant.

Means followed by the same letter within columns are not significantly different by Tukey's test $(\mathrm{P}<0.05)$. 
It is important to highlight that, contrary to what is observed in the fertile egg production system, using a 1:10 (Grunow et al., 2009) and 1:12 ratio of males to females (Embrapa, 2007), there was no plumage damage in the laying hens at the end of the experimental period.

The drinking behavior changed considerably only according to the observed period in the treatment with the presence of rooster. There was no significant statistical difference due to the introduction of roosters; drinking frequency remained the same in the full period (Table 4).

The increased water intake at the hottest time of the day is directly related to the increased demand for water to be used in the process of heat loss through evaporative processes. Many studies have suggested that endogenous heat production is associated with the lean tissue mass accrual of the individual (Brown-Brandl et al., 2004; Ball et al., 2008). This result can explain the increase in drinking behavior only in the barn with roosters, since they were heavier than the laying hens, which probably caused greater sensitivity to heat stress and dependency on the methods of latent heat dissipation.

The feeding behavior was not influenced by the presence of roosters or by the period of time observed (Table 4). This was found to be a high-priority behavior and, therefore, was displayed with a high frequency rate of 77.1-84.7\%.

In the evaluated production system, it was apparent that the greatest stimulus to food intake came from the sound produced with the activation of the automatic feeder. After hearing the sound, the birds approached the feeder and, for a few minutes, this was the prevailing behavior in the barns. Using the scanning technique, Pereira et al. (2015a) did not find a significant difference in the frequency of feeding behavior either. However, other authors, such as Barbosa Filho et al. (2007) and Silva et al. (2006), using the individual bird banding technique, reported a decrease in the frequency of feeding behavior with temperature increase.

The presence of roosters changed the frequency of the visit to the nest behavior only at $17.00 \mathrm{~h}$, when this activity was more frequent $(64.6 \%)$ in the barn with roosters. This behavior was directly associated with egg production and, therefore, it was displayed more frequently $(\mathrm{P}<0.05)$ in the morning. The frequency values in the barns with and without roosters were $91.7 \%$ and $82.6 \%$, respectively. The analysis in the full period demonstrated that this behavior changed considerably due to the presence of roosters (Table 4). In the barn with roosters, the frequency of $72.5 \%$ was recorded, whereas in the barn without roosters, the frequency was only $57.9 \%$. 
Duncan (1998) also reported the relationship between the nest visit frequency and egg laying. The author identified that nest visit is more frequent in the pre-laying period (1-2 $\mathrm{h}$ before laying) and reported that, when the birds are prevented from visiting the nest, they become frustrated and demonstrate it by crouching.

The time spent in the nest was statistically similar, regardless of the presence of roosters, but at $09.00 \mathrm{~h}$, it was statistically higher in both barns, which is consistent with literature data reporting a higher egg-laying rate in the morning hours. At $09.00 \mathrm{~h}$, frequencies of $91.0 \%$ and $83.3 \%$ were observed in the barns with and without roosters, respectively. In the other periods of time evaluated, frequency was lower than $17.0 \%$, characterizing the great influence of the period of the day.

According to Riber (2010), the use of nest boxes is an important part of the behavioral repertoire of laying hens kept under commercial conditions and, thus, they must be granted this right to minimize their stress and improve their welfare. Accordingly, it is worth mentioning that the egg laying rate on litter was low, which is in agreement with the findings of Barbosa Filho (2004), who found that after a period of acclimation, birds "learn" to use the nests.

With regard to the reproductive behaviors (Table 5), statistical analyses to compare courtship rituals and mating behavior data between the barns were not carried out because these behaviors were not displayed in the barn without roosters.

Both the courtship rituals and the mating behaviors changed significantly according to the period of time observed. Courtship rituals were less frequent in the morning and were performed at a frequency lower than 5\%.

The mating frequency was significantly higher $(\mathrm{P}<0.05)$ in the late afternoon than in the morning. During these periods of time, the frequency increased from $8.3 \%$ to $19.4 \%$ (Table 5). At $13.00 \mathrm{~h}$, the recorded frequency was similar to that of 9.00 and $17.00 \mathrm{~h}$ (Table 5).
Studying the behavior of birds, Campos (2000) suggested that the highest frequency of mating in the afternoon is associated with the lower egg production in this period of the day, which can be a strategy to facilitate the ascent of spermatozoa through the female reproductive tract, allowing fertilization. Thus, the results obtained in the present study corroborate those found by this author.

The tolerance-reflex behavior was more frequent in birds reared without the presence of roosters in all periods of time evaluated (Table 5). This behavior changed significantly $(\mathrm{P}<0.05)$ according to the observation time only in the shed without roosters; the highest frequency was observed in the afternoon $(55.1 \%)$ and the lowest in the morning $(22.5 \%)$. The analysis of the full period showed that this behavior changed considerably due to the presence of roosters.

The mating behavior reinforces the idea that the tolerance-reflex mechanism is indeed related to the lack of mating opportunities, since tolerance-reflex behaviors are more frequently displayed without the presence of roosters, and in the afternoon, when mating was also higher (Table 5). This result confirms that roosters are an important tool for behavioral freedom.

The frequency of agitation among the birds was lower than $5.0 \%$ in both barns and it did not change significantly due to the presence of roosters and the observation time ( $\mathrm{P}>0.05)$ (Table 6). It is possible that the roosters contributed to the low frequency observed, because even the birds housed without roosters were exposed to visual and auditory stimuli due to the proximity to the experimental barns, which might have given these birds a greater feeling of safety. Odén et al. (2015) found that laying hens reared with roosters demonstrated shorter periods of tonic immobility and low frequency of vigilance behavior, which are typical behavioral responses to fear. The authors concluded that the presence of roosters reduced fear in the laying hens.

Table 5 - Reproductive behaviors (\%) recorded in the barns with and without roosters in three periods of the day (8.00-9.00, 12.00-13.00, and $16.00-17.00 \mathrm{~h}$ ) and in the full period

\begin{tabular}{|c|c|c|c|c|c|c|c|c|c|}
\hline \multirow{3}{*}{ Barn } & \multicolumn{9}{|c|}{ Behavior } \\
\hline & \multicolumn{3}{|c|}{ Courtship rituals } & \multicolumn{3}{|c|}{ Mating } & \multicolumn{3}{|c|}{ Tolerance reflex } \\
\hline & $9.00 \mathrm{~h}$ & $13.00 \mathrm{~h}$ & $17.00 \mathrm{~h}$ & $9.00 \mathrm{~h}$ & $13.00 \mathrm{~h}$ & $17.00 \mathrm{~h}$ & $9.00 \mathrm{~h}$ & $13.00 \mathrm{~h}$ & $17.00 \mathrm{~h}$ \\
\hline With roosters & $4.9 \pm 2.8 b$ & $12.5 \pm 1.6 \mathrm{a}$ & $13.2 \pm 3.5 \mathrm{a}$ & $8.3 \pm 2.3 b$ & $13.2 \pm 3.3 \mathrm{ab}$ & $19.4 \pm 3.6 \mathrm{a}$ & $0.4 \pm 0.2 \mathrm{Ba}$ & $0.4 \pm 0.2 \mathrm{Ba}$ & $0.4 \pm 0.2 \mathrm{Ba}$ \\
\hline \multirow[t]{2}{*}{ Without roosters } & - & - & - & - & - & - & $22.5 \pm 3.7 \mathrm{Ac}$ & $36.6 \pm 2.4 \mathrm{Ab}$ & $55.1 \pm 3.7 \mathrm{Aa}$ \\
\hline & \multicolumn{9}{|c|}{ Full period } \\
\hline With roosters & \multicolumn{3}{|c|}{$10.2 \pm 1.7$} & \multicolumn{3}{|c|}{$13.6 \pm 1.9$} & \multicolumn{3}{|c|}{$0.4 \pm 0.1 \mathrm{~B}$} \\
\hline Without roosters & \multicolumn{3}{|c|}{ - } & \multicolumn{3}{|c|}{ - } & \multicolumn{3}{|c|}{$38.1 \pm 2.6 \mathrm{~A}$} \\
\hline
\end{tabular}

Means followed by the same uppercase letter within columns and lowercase letter within rows are not significantly different by Tukey's test at $5 \%$ probability level. $(-)$ : absent behavior. 
The frequency of fights changed significantly due to the presence of roosters and also according to the observed period. The barn with roosters showed higher frequency of fights in the late afternoon (6.2\%), differing statistically from the frequency recorded in the barn without roosters $(0.7 \%)$ (Table 6$)$. Interestingly, during that period of time, most of the fights involved roosters only. The higher frequency of mating recorded in the late afternoon (Table 5) is likely to have intensified the disputes over females, causing increased conflicts among roosters. However, it should be noted that this was a sporadic behavior, with frequency lower than $10 \%$, corroborating the reports of D'Eath and Keeling (2003), who also found lower frequency of aggressive behavior in birds reared in large groups.

Cannibalism was not observed (Table 6), which can be attributed mainly to the low idleness among the birds, because they were able to display several different behaviors. Rocha et al. (2008) stated that environmental enrichment is an important tool to minimize cannibalism. Janczak and Riber (2015) also pointed out that, as a result of a continuous genetic selection, it is possible that the current genotypes reared for egg production are less susceptible to feather-plucking and cannibalism, emphasizing that new studies are necessary to investigate the need to practice debeaking.

In the present study, we identified that the egg production system, rearing the birds on the floor, allowed the display of a wide range of behaviors indicative of welfare. The frequency of the following behaviors was recorded: dust bathing, flapping wings, stretching legs and wings, social interaction, shaking and fluttering feathers, and preening feathers (Table 7).

The display of the dust bathing behavior changed only according to the period of time observed. This variable was less frequent $(\mathrm{P}<0.05)$ in the morning in both barns. The analysis of the full period demonstrated that the frequency of this behavior was similar in the two barns.

Table 6 - Undesirable and agonistic behaviors (\%) recorded in the barns with and without roosters in three periods of the day (8.00-9.00, $12.00-13.00$, and $16.00-17.00 \mathrm{~h}$ ) and in the full period

\begin{tabular}{|c|c|c|c|c|c|c|c|c|c|}
\hline \multirow{3}{*}{ Barn } & \multicolumn{9}{|c|}{ Behavior } \\
\hline & \multicolumn{3}{|c|}{ Agitation } & \multicolumn{3}{|c|}{ Fighting } & \multicolumn{3}{|c|}{ Cannibalism } \\
\hline & $9.00 \mathrm{~h}$ & $13.00 \mathrm{~h}$ & $17.00 \mathrm{~h}$ & $9.00 \mathrm{~h}$ & $13.00 \mathrm{~h}$ & $17.00 \mathrm{~h}$ & $9.00 \mathrm{~h}$ & $13.00 \mathrm{~h}$ & $17.00 \mathrm{~h}$ \\
\hline With roosters & - & $2.8 \pm 1.2 \mathrm{Aa}$ & $2.8 \pm 1.9 \mathrm{Aa}$ & $2.1 \pm 1.1 \mathrm{Ab}$ & $1.4 \pm 0.9 \mathrm{Ab}$ & $6.2 \pm 2.1 \mathrm{Aa}$ & - & - & - \\
\hline Without roosters & $2.1 \pm 1.5 \mathrm{a}$ & \multicolumn{8}{|c|}{ Full period } \\
\hline With roosters & \multicolumn{3}{|c|}{$1.8 \pm 0.8 \mathrm{~A}$} & \multicolumn{3}{|c|}{$3.2 \pm 0.9 \mathrm{~A}$} & \multicolumn{3}{|c|}{ - } \\
\hline Without roosters & \multicolumn{3}{|c|}{$3.5 \pm 1.0 \mathrm{~A}$} & \multicolumn{3}{|c|}{$0.9 \pm 0.4 \mathrm{~B}$} & \multicolumn{3}{|c|}{ - } \\
\hline
\end{tabular}

Means followed by the same uppercase letter within columns and lowercase letter within rows are not significantly different by Tukey's test at $5 \%$ probability level. (-): absent behavior.

Table 7 - Behaviors indicative of welfare (\%), recorded in the barns with and without roosters, in three periods of the day (8.00-9.00, 12.00-13.00, and 16.00-17.00 h) and in the full period

\begin{tabular}{|c|c|c|c|c|c|c|c|c|c|}
\hline \multirow{3}{*}{ Barn } & \multicolumn{9}{|c|}{ Behavior } \\
\hline & \multicolumn{3}{|c|}{ Dust bathing } & \multicolumn{3}{|c|}{ Flapping wings } & \multicolumn{3}{|c|}{ Stretching legs and wings } \\
\hline & $9.00 \mathrm{~h}$ & $13.00 \mathrm{~h}$ & $17.00 \mathrm{~h}$ & $9.00 \mathrm{~h}$ & $13.00 \mathrm{~h}$ & $17.00 \mathrm{~h}$ & $9.00 \mathrm{~h}$ & $13.00 \mathrm{~h}$ & $17.00 \mathrm{~h}$ \\
\hline With roosters & $2.8 \pm 1.2 \mathrm{Ab}$ & $36.8 \pm 10.4 \mathrm{Aa}$ & $45.1 \pm 4.8 \mathrm{Aa}$ & $70.8 \pm 7.4 \mathrm{Aa}$ & $72.2 \pm 3.3 \mathrm{Aa}$ & $68.8 \pm 5.6 \mathrm{Aa}$ & $4.2 \pm 1.9 \mathrm{Aa}$ & $4.2 \pm 1.9 \mathrm{Aa}$ & $3.5 \pm 1.2 \mathrm{Aa}$ \\
\hline \multirow[t]{2}{*}{ Without roosters } & $2.1 \pm 1.6 \mathrm{Ac}$ & $30.6 \pm 7.4 \mathrm{Ab}$ & $53.5 \pm 7.3 \mathrm{Aa}$ & $62.5 \pm 7.6 \mathrm{Aa}$ & $45.8 \pm 6.5 \mathrm{Ba}$ & $51.4 \pm 5.8 \mathrm{Ba}$ & $6.2 \pm 2.1 \mathrm{Aa}$ & $4.2 \pm 1.3 \mathrm{Aa}$ & $2.8 \pm 1.2 \mathrm{Aa}$ \\
\hline & \multicolumn{9}{|c|}{ Full period } \\
\hline With roosters & \multicolumn{3}{|c|}{$28.7 \pm 4.9 \mathrm{~A}$} & \multicolumn{3}{|c|}{$70.6 \pm 3.2 \mathrm{~A}$} & \multicolumn{3}{|c|}{$3.9 \pm 1.0 \mathrm{~A}$} \\
\hline \multirow[t]{2}{*}{ Without roosters } & \multicolumn{3}{|c|}{$28.2 \pm 4.9 \mathrm{~A}$} & \multicolumn{3}{|c|}{$53.2 \pm 3.9 \mathrm{~B}$} & \multicolumn{3}{|c|}{$4.4 \pm 0.9 \mathrm{~A}$} \\
\hline & \multicolumn{3}{|c|}{ Social interaction } & \multicolumn{3}{|c|}{ Shaking and fluttering feathers } & \multicolumn{3}{|c|}{ Preening feathers } \\
\hline With roosters & $13.9 \pm 3.0 \mathrm{Aa}$ & $24.3 \pm 4.0 \mathrm{Aa}$ & $24.3 \pm 3.3 \mathrm{Aa}$ & $31.9 \pm 3.1 \mathrm{Aa}$ & $34.7 \pm 4.5 \mathrm{Aa}$ & $32.6 \pm 4.2 \mathrm{Ba}$ & $86.1 \pm 3.5 \mathrm{Aa}$ & $65.3 \pm 5.4 \mathrm{Ab}$ & $55.6 \pm 6.5 \mathrm{Ab}$ \\
\hline \multirow[t]{2}{*}{ Without roosters } & $13.1 \pm 2.6 \mathrm{Aa}$ & $22.9 \pm 3.7 \mathrm{Aa}$ & $17.4 \pm 2.6 \mathrm{Aa}$ & $36.8 \pm 3.2 \mathrm{Aa}$ & $36.1 \pm 3.9 \mathrm{Aa}$ & $47.2 \pm 4.3 \mathrm{Aa}$ & $86.1 \pm 5.2 \mathrm{Aa}$ & $70.1 \pm 5.7 \mathrm{Aa}$ & $61.8 \pm 6.5 \mathrm{Ab}$ \\
\hline & \multicolumn{9}{|c|}{ Full period } \\
\hline With roosters & \multicolumn{3}{|c|}{$19.9 \pm 2.2 \mathrm{~A}$} & \multicolumn{3}{|c|}{$33.1 \pm 2.2 \mathrm{~B}$} & \multicolumn{3}{|c|}{$72.7 \pm 2.2 \mathrm{~A}$} \\
\hline Without roosters & \multicolumn{3}{|c|}{$18.0 \pm 1.8 \mathrm{~A}$} & \multicolumn{3}{|c|}{$40.0 \pm 2.3 \mathrm{~A}$} & \multicolumn{3}{|c|}{$69.0 \pm 1.8 \mathrm{~A}$} \\
\hline
\end{tabular}

Means followed by the same uppercase letter within columns and lowercase letter within rows are not significantly different by Tukey's test at $5 \%$ probability level. 
According to Santos et al. (2010), dust bathing is a mechanism of heat exchange with the environment. This may explain the fact that this behavior was more frequent at the hottest times of the day, between 13.00 and $17.00 \mathrm{~h}$, whereas at 9:00 h, its frequency was lower than 3.0\%. Pereira et al. (2007) reported that the frequency of dust bathing is positively correlated with temperature. According to the European Commission (2000), this is considered important for birds because it helps maintain plumage in good condition.

It was noted that when given the chance to choose, birds prefer to take dust baths in sunny places. It is believed that the main factors influencing such preference are: the litter is usually drier and softer, facilitating the bedding material to spread over the legs of the birds; the exposure to sunlight aids in the control of ectoparasites; and when loose bedding material is thrown into the air it reflects sun light, which can stimulate the curiosity of the birds. Petherick et al. (1995) reported that litter is an important visual stimulus to birds and is one of the main factors that trigger the dust bathing behavior.

There was a significant difference in the frequency of the flapping wing behavior due to the presence of roosters between 13.00 and $17.00 \mathrm{~h}$. During this period, their presence significantly increased the display of this behavior, which reached $72.2 \%$ and $68.8 \%$, respectively, whereas in the barn without roosters, the frequency was, respectively, $45.8 \%$ and $51.4 \%$. The evaluation of the full period indicated that the frequency of this behavior was different in the two barns, but no difference $(\mathrm{P}>0.05)$ was found between the observation times in the analysis of the same barn.

The observations made in the present study demonstrated that this behavior was more frequently displayed by the roosters, in agreement with the report by Wood-Gush (1956), according to whom this is a typical behavior of roosters during aggressive contacts and when courting females. Leonard and Zanette (1998) studied the behavior of roosters and identified an increase in the frequency of this behavior when laying hens were around. The authors defined it as a mechanism of body exhibition that influences the choice of roosters to mate.

The frequency of stretching legs and wings behavior was similar $(\mathrm{P}>0.05)$ in both barns and it was not significantly different over the observation period (Table 7). Pereira et al. (2013) evaluated the behavior of laying hens and, similarly to our findings, they also observed low frequency of this behavior, 2.8\%-6.2\%. Among all behaviors indicative of welfare, flapping wings was the one with the lowest frequency.
The frequency of social interactions behavior did not change according to the studied variables (presence of roosters and different periods of time); there was no significant difference in the full period either $(\mathrm{P}>0.05)$. The occurrence of this behavior varied between $13.1 \%$ and $24.3 \%$; therefore, it can be said that it was a very frequent behavior among the birds.

The hens showed strong tendency to interact with the roosters by cleaning their feathers and giving them many delicate quick pecks, usually on the face side. These forms of interaction were less frequent in the barns without roosters. Without the males, the predominant forms of interaction were collective dust baths and the act of scratching the ground together searching for insects and/or objects in the litter.

The presence of roosters caused a significant decrease in the frequency of the shaking and fluttering feathers behavior in the afternoon. During this period of time, this behavior was displayed at a frequency of $32.6 \%$, whereas in the barn without roosters, the frequency was $47.2 \%$. Considering that the allocation of time and resources to different physical or behavioral activities is controlled by motivational mechanisms, it is hypothesized that the frequency reduction observed is associated with the higher frequency of other behaviors performed during this period, e.g., the reproductive behaviors.

The same behavior was displayed with a relatively similar frequency in the different periods of the day; in other words, the frequency of the behavior did not change according to the observation time, probably because it was more closely related to the act of straightening the feathers than to the attempts to dissipate heat. Pereira et al. (2005) did not identify the influence of period of time on the frequency of this behavior either. Preening feathers was also described as a behavior inherent to the species and indicative of welfare. Its frequency changed according to the observation period and the presence of roosters $(\mathrm{P}>0.05)$. The barn with roosters showed higher frequency in the morning $(86.1 \%)$, whereas the barn without roosters showed higher frequencies in the morning and midday, $86.1 \%$ and $70.1 \%$, respectively (Table 7 ).

It was found that, among all behaviors that indicate welfare, this was the most frequently displayed behavior by the birds in the morning. Furthermore, it was possible to identify that this behavior was systematically more frequently exhibited by the birds sitting on the perch, whereas the birds on the floor were more engaged in other activities such as feeding, drinking, and interacting with the litter. 


\section{Conclusions}

This alternative egg production system proved to promote animal welfare since it provides and stimulates the display of behaviors considered important for birds. In this production system, the presence of roosters stimulates the display of reproductive behaviors, thus broadening the repertoire of natural behaviors of birds. Moreover, their presence significantly reduces tolerance-reflex behavior, which is associated with the lack of mating opportunities.

\section{Acknowledgments}

The authors thank the Centro de Pesquisa Mokiti Okada and the Korin Agropecuária company for funding this research.

\section{References}

Armstrong, D. V. 1994. Heat stress interaction with shade and cooling. Journal of Dairy Science 77:2044-2050.

Baêta, F. C. and Souza, C. F. 1997. Ambiência em edificações rurais: conforto térmico animal. 2.ed. Universidade Federal Viçosa, Viçosa, MG.

Ball, R. O.; Samuel, R. S. and Moehn, S. 2008. Nutrient requirements of prolific sows. Advances in Pork Production Journal 19:223-236.

Barbosa Filho, J. A. D. 2004. Avaliação do bem estar de aves poedeiras em diferentes sistemas de produção e condições ambientais, utilizando análise de imagem. Dissertação (M.Sc.). Escola Superior de Agricultura "Luiz de Queiroz", Piracicaba.

Barbosa Filho, J. A. D.; Silva, I. J. O.; Silva, N. A. and Silva, C. J. M. 2007. Avaliação dos comportamentos de aves poedeiras utilizando sequência de imagens. Revista Engenharia Agrícola 27:93-99.

Brown-Brandl, T. M.; Nienaber, J. A., Xin, H. and Gates, R. S. 2004. A literature review of swine heat production. Transactions of the ASAE 47:259-270.

Buffington, D. E.; Collazo-Arocho, A.; Canton, G. H.; Pitt, D.; Hatcher, W. W. and Collier, R. J. 1981. Black globe-humidity index (BGHI) as comfort equation for dairy cows. Transactions American Society Agricultural Engineer 24:711-714.

Campos, E. J. O. 2000. Comportamento das aves. Revista Brasileira de Ciência Avícola 2:93-113.

D'Eath, R. B. and Keeling, L. J. 2003. Social discrimination and aggression by laying hens in large groups: from peck orders to social tolerance. Applied Animal Behaviour Science 84:197-212.

Duncan, I. J. 1998. Behavior and behavioral needs. Poultry Science 77:1766-1772

Embrapa - Empresa Brasileira de Pesquisa Agropecuária. 2007. Sistema alternativa de criação de galinhas caipiras. Embrapa Meio Norte, Teresina. Available at: <http://sistemasdeproducao.cnptia. embrapa.br/FontesHTML/Ave/SistemaAlternativoCriacaoGalinh aCaipira/Reproducao.htm>. Accessed on: Jan. 14, 2014.

European Commission. 2000. Health e Consumer Protection Directorate-General. The Welfare of chickens kept for meat production (broilers). Report for the Scientific Committee on Animal Health and Animal Welfare. Available at: $<$ http://ec.europa. eu/food/fs/sc/scah/out39_en.pdf >. Accessed on: July 06, 2016.
FAWC - Farm Animal Welfare Council. 1993. Farm Animal Welfare Council: Report on priorities for animal welfare research and development, London. 27p.

Ferreira, R. A. 2005. Maior produção com melhor ambiente para aves, suínos e bovinos. 1.ed. Aprenda Fácil, Viçosa.

Furlan, R. A. 2001. Avaliação da nebulização e abertura de cortinas na redução da temperatura do ar em ambiente protegido. Tese (D.Sc.) Escola Superior de Agricultura "Luiz de Queiroz", Piracicaba, SP, Brasil.

Grunow, A.; Gallon, A.V. and Beuren, I. M. 2009. Análise da cadeia de valor e dos custos das rações de uma agroindústria processadora de aves. Organizações Rurais \& Agroindustriais 11:205-221.

HFAC - Humane Farm Animal Care. 2014. Animal care standards - Egg laying hens. Available at: <http://certifiedhumane.org/wp-content/ uploads/2014/08/Std14.Layers.5Z.pdf $>$. Accessed on: Apr. 09, 2015.

Hendrix Genetics. 2012-2013. Isa Brown management guide. Available at: <http://www.joiceandhill.co.uk/ /media/Files/Joice\% 20 and $\% 20 \mathrm{Hill} /$ technical$\% 20$ guides/isa $\% 20$ brown/ISA\%20Brown $\% 20$ Management\%20Guide.pdf $>$. Accessed on: July 06, 2016.

Janczak, A. M. and Riber, A. B. 2015. Review of rearing-related factors affecting the welfare of laying hens. Poultry Science 94:1454-1469.

Leonard, M. L. and Zanette L. 1998. Female mate choice and male behaviour in domestic fowl. Animal Behaviour 56:1099-1105.

Leonard, M. L.; Zanette, L. and Fairfull, R. W. 1993. The effect of early exposure to the opposite sex on mate choice in white leghorn chickens. Applied Animal Behaviour Science 36:29-38.

Newberry, R. C. 1995. Environmental enrichment: increasing the biological relevance of captive environments. Applied Animal Behaviour Science 44:229-243.

Odén, K.; Gunnarsson, S.; Berg, C. and Algers, B. 2015. Effects of sex composition on fear measured as tonic immobility and vigilance behavior in large flocks of laying hens. Applied Animal Behaviour Science 95:89-102.

Pereira, D. F.; Nääs, I. A.; Romanini, C. E. B.; Salgado, D. D. and Pereira, G. O. T. 2005. Indicadores de bem-estar baseados em reações comportamentais de matrizes pesadas. Revista Engenharia Agrícola 25:308-314.

Pereira, D. F.; Nääs, I. A.; Salgado, D. D.; Gaspar, C. R.; Bighi, C. A.; Penha, N. L. J. 2007. Correlations among behavior, performance and environment in broiler breeders using multivariate analysis. Brazilian Journal of Poultry Science 9:207-213.

Pereira, D. F.; Batista, E. S.; Sanches, F. T.; Gabriel Filho, L. R.A. and Bueno, L. G. F. 2013. Comportamento de poedeiras criadas em diferentes densidades e tamanhos de grupo em ambiente enriquecido. Pesquisa Agropecuária Brasileira 48:682-688.

Pereira, D. F.; Batista, E. S.; Sanches, F. T.; Gabriel Filho, L. R. A. and Bueno, L. G. F. 2015a. Diferenças comportamentais de poedeiras em diferentes ambientes térmicos. Energia na Agricultura 30:33-40.

Pereira, D. C. O.; Miranda, K. O. S. and Demattê Filho, L. C. 2015b. De olho no bem-estar animal sem perder o foco na produtividade. Avicultura Industrial 106:46-48.

Petherick, J. C.; Seawright, E.; Waddington, D. and Duncan, I. A. J. and Murphy, L. B. 1995. The role of perception in the causation of dustbathing behaviour in domestic fowl. Animal Behaviour 49:1521-1530.

Riber, A. B. 2010. Development with age of next box use and gregarious nesting in laying hens. Applied Animal Behaviour Science 123:24-31.

Rocha, J. S. R.; Lara, L. C. and Baião, N. C. 2008. Produção e bemestar animal: Aspectos éticos e técnicos da produção intensiva de aves. Ciência Veterinária nos Trópicos 11:49-55.

Santos, M. J. B.; Pandorfi, H.; Almeida, G. L. P.; Morril, W. B.; Pedrosa, E. M. R. and Guiselini, C. 2010. Comportamento bioclimático 
de frangos de corte caipira em piquetes enriquecidos. Revista Brasileira de Engenharia Agrícola e Ambiental 14:554-560.

Silva, I. J. O.; Barbosa Filho, J. A. D.; Silva, M. A. N. and Piedade, S. M. S. 2006. Influência do sistema de criação nos parâmetros comportamentais de duas linhagens de poedeiras submetidas a duas condições ambientais. Revista Brasileira de Zootecnia 35:1439-1446.

Thaxton, Y. V.; Christensen, K. D.; Mench, J. A.; Rumley, E. R.; Daugherty, C.; Feinberg, B.; Parker, M.; Siegel, P. and Scanes,
C. G. 2016. Symposium: Animal welfare challenges for today and tomorrow. Poultry Science 95:2198-2207.

Tinôco, I. F. F. 1998. Ambiência e instalações para a avicultura industrial. p.1-86. In: Anais do Congresso Brasileiro de Engenharia Agrícola. Sociedade Brasileira de Engenharia Agrícola, Poços de Caldas.

Wood-Gush, D. G. M. 1956. The agonistic and courtship behaviour of the brown leghorn cock. British Journal of Animal Behaviour 4:133-142. 